\title{
OKTAGONÁLIS LAPKA ALKALMAZÁSA SORÁN MÉRT FORGÁCSOLÓERŐ VIZSGÁLATA ÉS ÖSSZEHASONLÍTÁSA MÁS LAPKA GEOMETRIÁKKAL HOMLOKMARÁS ESETÉN
}

\author{
Makkai Tamás \\ tanársegéd, Miskolci Egyetem, Gyártástudományi Intézet \\ 3515 Miskolc, Miskolc-Egyetemváros, e-mail: tamas.makkai@uni-miskolc.hu
}

\begin{abstract}
Absztrakt
A termelékenység növelése versenyelönyt jelent a termelö vállalatoknál, ezért annak kutatása az egyik meghatározó irányvonalat képviseli a forgácsoló megmunkálások területén. A hatékonyságot a technológiai paraméterek módositásával lehet befolyásolni. Homlokmarás esetén az egyik módszere a termelékenység növelésének az, ha az egy élre jutó elötolást növeljük. Ebben a cikkben bemutatásra kerül egy nyolcszögletü lapkával végzett forgácsolási kísérlet, valamint annak eredményei. Állandó fogásmélység és állandó forgácsoló sebesség mellett ötféle fogankénti elötolás alkalmazásával vizsgáltam az elötolás hatását a forgácsolóerökre ötvözetlen acél homlokmarásánál. A kisérlet eredményeit felhasználva, valamint az elözö kísérletek eredményeivel összevetve elemeztem a fajlagos forgácsolóerö változását négy különbözö lapkageometria (lapkaalak) esetén. Ebböl megállapítottam, hogy energiafelhasználás szempontjából legelönyösebb a vizsgált lapkák közül a téglalap, majd a négyzet, a nyolcszög és a kör alakú lapka alkalmazása a vizsgált paramétertartományban.
\end{abstract}

Kulcsszavak: homlokmarás, forgácsolóerö, fajlagos forgácsolóerö, nyolcszögletü lapka, lapkageometria összehasonlitása

\begin{abstract}
Increasing productivity is a competitive advantage for manufacturing companies, so its research represents one of the defining directions in the field of machining. Efficiency can be affected by modifying technological parameters. One way to increase productivity is to increase the feed per tooth in face milling. This paper presents a cutting experiment with an octagonal insert and its results. At a constant depth of cut and a constant cutting speed, I investigated the effect of the feed on the cutting forces in face milling of non-alloy steel using five feeds per tooth. Using the results of the experiment and comparing them with the results of previous experiments, I analysed the changes in specific cutting force for four different insert geometries (insert shapes). From this, I concluded that the most advantageous from the point of view of energy consumption is the use of rectangular, then square, octagonal and circular inserts in the examined parameter range.
\end{abstract}

Keywords: face milling, cutting force, specific cutting force, octagonal insert, insert shapes comparison

\section{Bevezetés}

Síkfelületek elöállítására a homlokmarást előszeretettel alkalmazzák, jó felületminőség és pontosság mellett a termelékenysége is kiváló. A homlokmarás termelékenységének növelését az előtolási sebesség növelésével [1] lehet megvalósítani, azaz a fogankénti elötolás és a forgácsolósebesség növelése teszi azt lehetővé. A megmunkálás során ébredő terhelések hatással vannak a munkadarabra és a szer- 
számra, illetve a teljes MKGS rendszerre. A nemzetközi és a hazai szakirodalomban számos cikk foglalkozik homlokmarás esetén a forgácsolóerő vizsgálatával. Li és társai [2] a homlokmarásnál fellépő forgácsolóerők elméleti modellezését és szimulációját mutatták be új megközelítésben. A modellezés során a szerszám müködését több egyélü forgácsolószerszám egyidejü munkájaként vették figyelembe.

A lapkageometriai jellemzői, mint például a csúcssugár, a föélelhelyezési szög és a homlokszög is szintén jelentős szerepet játszhatnak a folyamat kimenetelében, mivel befolyásolják a forgácsolóél terhelési körülményeit, valamint a felületi érdességet is, így a megfelelő geometriájú lapka kiválasztása döntő jelentőségü. Felhő és Kundrák kétféle marószerszámmal [3] és speciális kialakítású maróval [4] hasonlították össze az elméleti és a valós felületi érdességet. Megállapították, hogy nyolcszögletü lapka esetén a felületi érdesség jól közelít az elméleti értékhez, a körlapka alkalmazása során pedig egyéb tényezők hatása erősebb. Maráshoz a leggyakrabban téglalap, négyzet és kör alakú lapkák használatosak [5]. A kör alakú lapkák bizonyos sajátosságokat mutatnak a különleges formájuk miatt, a fóélelhelyezési szög értéke változó, az erő- és a hőeloszlás egyenletesebb, a forgács vastagsága a forgácsolóél mentén változik [6,7].

Homlokmarási kísérletek során Korkut és Donertas [8] a forgács keresztmetszetétôl és a forgácsolási sebességtől függően kiértékelték a forgácsolóerőket és a felületi érdességeket kétféle acél munkadarabnál. Azt tapasztalták, hogy bizonyos forgácsolási paraméter tartományon belül a növekvő forgácsolósebesség növelte a forgácsolóerőket, míg alacsonyabb és közepes sebességnél a marószerszám élrátét kialakulási hajlama megnőtt.

Gurdal és társai [9] összehasonlították a különféle marólapkák (négyzetes, kör és egy nagy elötolású) teljesítményét nagyoló marás során. Hangsúlyozták a fóélelhelyezési szög fontosságát, amely befolyásolja a forgács alakját és vastagságát, valamint a forgácsolóerő eloszlását a szerszámon. Megállapították, hogy a nagyoló marás során a kisebb főélelhelyezési szöggel rendelkező lapkák javíthatják a termelékenységet és csökkenthetik a rezgéseket, a négyzetes lapkák pedig nagyobb szerszámkopást mutattak.

A szerszámgeometria hatással van a megmunkált felület minőségére. Suresh Kumar Reddy és Venkateswara Rao [10] kísérleti vizsgálatokkal meghatározták a szerszámgeometria (radiális homlokszög és csúcssugár) és a forgácsolási körülmények (forgácsolósebesség és előtolási sebesség) hatását a megmunkálási teljesítményre szénacél marása során. A felületi érdesség előrejelzési modelljének optimalizálására genetikai algoritmusokat alkalmaztak, így egy olyan módszert alkottak, amely megadja a megmunkálási paramétereket a lehető legjobb felületminőség eléréséhez.

Korábbi publikációkban bemutattuk C45 acél homlokmarásánál az előtolásnak és a forgácsoló sebességnek a forgácsolóerő összetevőire gyakorolt hatását mind a munkadarab, mind a szerszám koordináta rendszerében értelmezve [11]. Megvizsgáltuk a különféle alakú forgács keresztmetszetek és az előtolás hatását a forgácsolóerő komponensekre, valamint a megmunkált felület érdességére [12]. Öszszehasonlítottuk a különféle alakú (téglalap, kör és négyzet) lapkákkal végzett homlokmarásnál a forgácsolóerő összetevőinek a változását [13]. Vizsgáltam a forgácsolósebesség hatását a forgácsolóerőre és fajlagos forgácsolóerőre nyolcszögletü lapka alkalmazása esetén [14].

A termelékenységet az előtolás növelésével is lehet növelni, ebben a cikkben a fogankénti elötolás hatását vizsgálom meg a forgácsolóerő és a fajlagos forgácsolóerő összetevőire. Ennek eredményeit és a korábbi kísérletek [13] eredményeit felhasználva a négyféle lapkageometria (alak) esetében összehasonlító elemzést is közlök, a fogankénti előtolás és a fellépő terhelés (forgácsolóerő és fajlagos forgácsolóerő összetevői) függvényében. 


\section{Kísérleti feltételek}

A kísérletek egy Perfect Jet MCV-M8 (H) függőleges tengelyü megmunkáló központon zajlottak. Az alkalmazott szerszám egy ATORN OCKX 0606-AD-TR HC4640 típusú bevonatos keményfém lapka volt $\left(\gamma_{0}=25^{\circ} ; \alpha_{o}=7^{\circ} ; r_{\varepsilon}=0,5 \mathrm{~mm}\right)$, mely egy ATORN 10612120 típusú homlokmaró fejbe volt szerelve $\left(\mathrm{D}=80 \mathrm{~mm}, \kappa_{\mathrm{r}}=43^{\circ}\right)$. A marófejbe csak egy darab marólapka került (1. ábra), hogy a forgácsolóerő összetevőinek a változását a többi él kölcsönhatása nélkül tudjam rögzíteni, vagyis egyetlen forgácsolóél hatását tudjam vizsgálni. A munkadarab C45 ötvözetlen szénacélból készült, a forgácsolt felület $58 \times 50 \mathrm{~mm}$ volt. A forgácsolási adatokat az 1. táblázat tartalmazza. A környezet terhelésének csökkentése érdekében szárazmegmunkálás történt, hűtőfolyadékot nem alkalmaztunk a kísérlet során.

1. táblázat. Forgácsolási adatok

\begin{tabular}{|l|c|c|}
\hline Megnevezés & Jelölés & Érték \\
\hline forgácsolósebesség & $\mathrm{v}_{\mathrm{c}}$ & $200 \mathrm{~m} / \mathrm{min}$ \\
\hline foorsó fordulatszám & $\mathrm{n}_{\mathrm{s}}$ & $909,461 / \mathrm{min}$ \\
\hline fogásszélesség & $\mathrm{b}_{\mathrm{w}}$ & $58 \mathrm{~mm}$ \\
\hline fogásmélység & $\mathrm{a}_{\mathrm{p}}$ & $0,8 \mathrm{~mm}$ \\
\hline fogankénti elötolás & $\mathrm{f}_{\mathrm{z}}$ & $0,1-0,8 \mathrm{~mm} / \mathrm{fog}$ \\
\hline
\end{tabular}

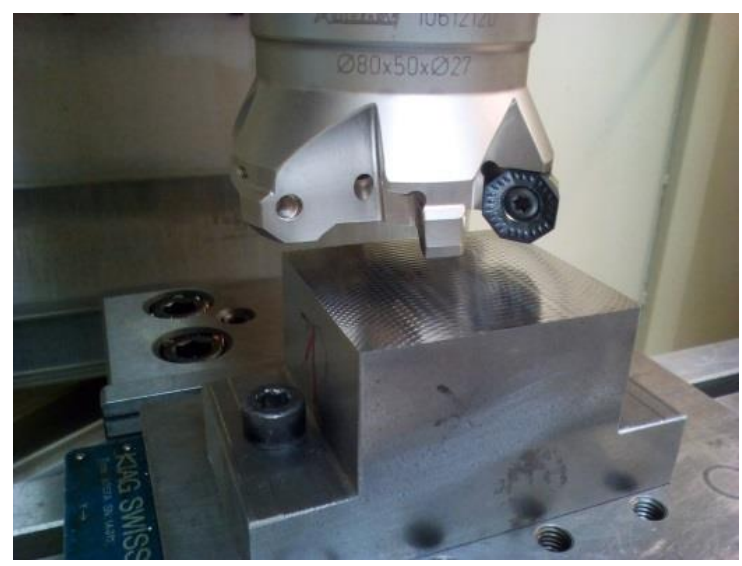

1. ábra. A kisérleteknél alkalmazott szerszám és munkadarab

A kísérleteknél alkalmazott erőmérő rendszer:

- egy Kistler gyártmányú 9257A típusú három komponensủ dinamométer,

- 3 darab Kistler 5011A töltéserősítő,

- egy National Instruments gyártmányú 4 csatornás CompactDAQ-9171 adatgyüjtő egység,

- laptop, LabView programnyelven készült mérőszoftverrel.

A megmunkálás közben mindhárom irányú, munkadarab koordináta rendszerében értelmezett erökomponens $\left(\mathrm{F}_{\mathrm{x}}, \mathrm{F}_{\mathrm{y}}\right.$ és $\left.\mathrm{F}_{\mathrm{z}}\right)$ értéke folyamatosan rögzítésre került, a mintavételi frekvencia $10 \mathrm{kHz}$-re volt megadva. Szimmetrikus homlokmarás volt beállítva, azaz a szerszám forgástengelye a munkadarab szimmetria síkjában haladt. 


\section{Kísérleti eredmények}

A kísérleteket állandó fogásmélység és állandó forgácsolósebesség beállításával végeztem, a fogankénti előtolás értékeit pedig változtattam, ezek $0,1-0,2-0,3-0,4-0,8 \mathrm{~mm} /$ fog értékre voltak beállítva. A kísérletek során az előzőekben már bemutatott erőmérő rendszerrel mértem az $F_{x}, F_{y}$ és $F_{z}$ erőkomponenseket (munkadarabhoz kötött álló koordináta rendszerben), majd ezek alapján kiszámítottam az $F_{c}, F_{f}$ és $F_{p}$ erőkomponenseket (szerszámhoz kötött forgó koordináta rendszerben). A mért és a számított erökomponensek maximális értékei a 2. táblázatban láthatók összefoglalva mind az ötféle fogankénti előtolásra vonatkozóan, ezeket a 2. ábra diagram formájában is szemlélteti.

\section{2. táblázat}

A mért és a számitott erőkomponensek maximális értékeinek összefoglalása

\begin{tabular}{|c|c|c|c|c|c|c|}
\hline \multirow{2}{*}{$\begin{array}{c}\text { Fogankénti } \\
\text { előtolás }\end{array}$} & \multicolumn{5}{|c|}{ Erőkomponensek } \\
\cline { 2 - 7 } & \multicolumn{3}{|c|}{ Mért } & \multicolumn{3}{|c|}{ Számított } \\
\hline $\mathrm{f}_{\mathrm{z}}$ & $\mathrm{F}_{\mathrm{x}}$ & $\mathrm{F}_{\mathrm{y}}$ & $\mathrm{F}_{\mathrm{z}}$ & $\mathrm{F}_{\mathrm{c}}$ & $\mathrm{F}_{\mathrm{f}}$ & $\mathrm{F}_{\mathrm{p}}$ \\
\hline$[\mathrm{mm} / \mathrm{fog}]$ & {$[\mathrm{N}]$} & {$[\mathrm{N}]$} & {$[\mathrm{N}]$} & {$[\mathrm{N}]$} & {$[\mathrm{N}]$} & {$[\mathrm{N}]$} \\
\hline 0,1 & 213,14 & 261,49 & 361,26 & 212,02 & 174,99 & 361,26 \\
\hline 0,2 & 312,54 & 401,26 & 460,53 & 357,26 & 213,58 & 460,53 \\
\hline 0,3 & 391,12 & 521,57 & 532,81 & 461,08 & 275,05 & 532,81 \\
\hline 0,4 & 459,13 & 636,50 & 581,17 & 567,40 & 315,30 & 581,17 \\
\hline 0,8 & 715,60 & 1112,67 & 771,94 & 1045,55 & 419,35 & 771,94 \\
\hline
\end{tabular}

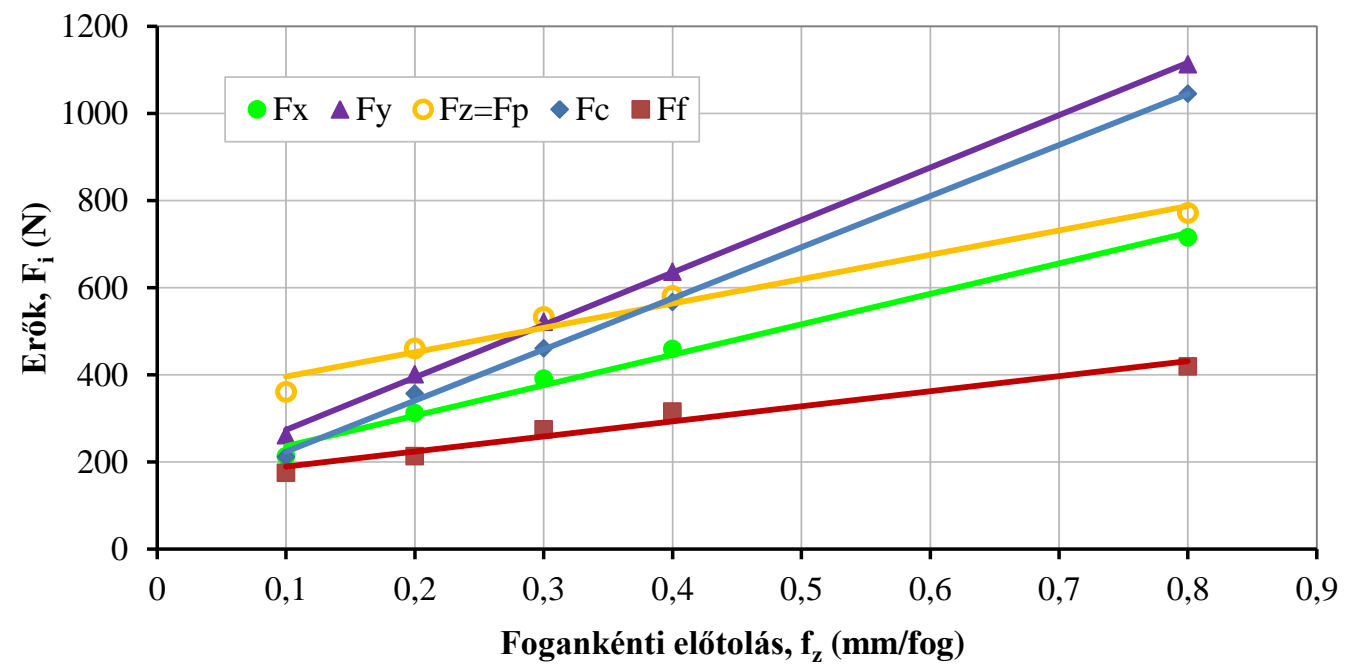

2. ábra. A mért és a számított erökomponensek maximális értékeinek változása a fogankénti elötolás függvényében 
Mindegyik erőkomponens esetében megfigyelhető, hogy azok közel lineárisan növekednek a fogankénti előtolás növelésével. A növekedés mértéke a vizsgált fogankénti előtolás tartományban az $\mathrm{F}_{\mathrm{z}}\left(=\mathrm{F}_{\mathrm{p}}\right)$ és az $\mathrm{F}_{\mathrm{f}}$ esetén kisebb $(214 \%$, illetve $240 \%)$, míg az $\mathrm{F}_{\mathrm{y}}$ és az $\mathrm{F}_{\mathrm{c}}$ esetén a növekvő tendencia közel párhuzamos görbéket mutat, a növekedésük mértéke pedig 426\% és 493\%. Az alapsíkban megjelenő terhelésről elmondható, hogy az y irányú összetevője $\left(\mathrm{F}_{\mathrm{y}}\right)$ nagyobb az x irányú $\left(\mathrm{F}_{\mathrm{x}}\right)$ összetevőjénél a teljes vizsgálati tartományban. A fogankénti előtolás növelésével a különbség még markánsabban jelenik meg. A szerszámot érő terhelés tangenciális összetevője, azaz a föforgácsolóerő $\left(F_{c}\right)$ növekedése is nagyobb mértékü, mint a radiális összetevő $\left(\mathrm{F}_{\mathrm{f}}\right)$ növekedése. A szerszám föorsóját terhelö $\mathrm{F}_{\mathrm{p}}$ erőkomponens esetében a változás kedvező, hiszen a fogankénti előtolás nyolcszorosára való növelése mellett az $\mathrm{F}_{\mathrm{p}}$ csak a duplájára nőtt.

Energetikai szempontból a fajlagos forgácsolóerő meghatározásával lehet értékelni a fogankénti előtolás hatását. Mivel a kísérletek során a fogankénti előtolás változó paraméter volt, így a deformálatlan forgácskeresztmetszet is változott. A számítással meghatározott fajlagos erőkomponensek maximális értékei a 3. táblázatban láthatók összefoglalva az öt alkalmazott fogankénti előtolás esetében. A 3. ábra pedig a fajlagos erőkomponensek maximális értékeinek változását mutatja a fogankénti elötolásokra vonatkozóan.

\section{3. táblázat}

A mért és a számitott erökomponensek maximális fajlagos értékeinek összefoglalása

\begin{tabular}{|c|c|c|c|c|c|c|}
\hline \multirow{2}{*}{$\begin{array}{c}\text { Fogankénti } \\
\text { előtolás }\end{array}$} & \multicolumn{5}{|c|}{ Fajlagos erőkomponensek } \\
\cline { 2 - 7 } & $\mathrm{k}_{\mathrm{x}}$ & $\mathrm{k}_{\mathrm{y}}$ & $\mathrm{k}_{\mathrm{z}}$ & $\mathrm{k}_{\mathrm{c}}$ & $\mathrm{k}_{\mathrm{f}}$ & $\mathrm{k}_{\mathrm{p}}$ \\
\hline $\mathrm{f}_{\mathrm{z}}$ & {$\left[\mathrm{N} / \mathrm{mm}^{2}\right]$} & {$\left[\mathrm{N} / \mathrm{mm}^{2}\right]$} & {$\left[\mathrm{N} / \mathrm{mm}^{2}\right]$} & {$\left[\mathrm{N} / \mathrm{mm}^{2}\right]$} & {$\left[\mathrm{N} / \mathrm{mm}^{2}\right]$} & {$\left[\mathrm{N} / \mathrm{mm}^{2}\right]$} \\
\hline$[\mathrm{mm} / \mathrm{fog}]$ & 2664,22 & 3268,61 & 4515,69 & 2650,28 & 2187,43 & 4515,69 \\
\hline 0,1 & 1953,35 & 2507,90 & 2878,29 & 2232,90 & 1334,86 & 2878,29 \\
\hline 0,2 & 1629,65 & 2173,19 & 2220,03 & 1921,18 & 1146,05 & 2220,03 \\
\hline 0,3 & 1434,80 & 1989,07 & 1816,14 & 1773,13 & 985,31 & 1816,14 \\
\hline 0,4 & 1118,13 & 1738,55 & 1206,15 & 1633,66 & 655,23 & 1206,15 \\
\hline 0,8 &
\end{tabular}

A fogankénti előtolással arányosan növekvő deformálatlan forgácskeresztmetszet leválasztása nagyobb forgácsolóerőt igényel. Viszont az egységnyi forgácskeresztmetszet leválasztásához szükséges erő - mint ahogy a 3. táblázatban és a 3. ábrán megjelenik - csökkenő jelleget mutat. Legnagyobb mértékủ a csökkenés a vizsgált fogankénti elötolás tartományban a $\mathrm{k}_{\mathrm{z}}\left(=\mathrm{k}_{\mathrm{p}}\right)$ esetén, ahol $\sim 500 \mathrm{~N} / \mathrm{mm}^{2}$ röl $\sim 1200 \mathrm{~N} / \mathrm{mm}^{2}$-re csökkent, ami közelítőleg 73\%-os csökkenést jelent. A munkadarab koordinátarendszerében meghatározott $\mathrm{x}$ és y irányú összetevők csökkenése $\mathrm{k}_{\mathrm{x}}$ esetében $58 \%$, $\mathrm{k}_{\mathrm{y}}$ esetében pedig 47\%. A szerszám koordináta rendszerében meghatározott $\mathrm{k}_{\mathrm{c}}$ komponens $\sim 2650 \mathrm{~N} / \mathrm{mm}^{2}$-röl $\sim 1630 \mathrm{~N} / \mathrm{mm}^{2}$-re csökkent (-38\%), a $\mathrm{k}_{\mathrm{f}}$ komponens pedig $2200 \mathrm{~N} / \mathrm{mm}^{2}$-röl $\sim 650 \mathrm{~N} / \mathrm{mm}^{2}$-re csökkent $(-70 \%)$. Az elvégzett kísérletek és az adatok kiértékelése alapján megállapítom, hogy az alkalmazott paraméterek esetén a fogankénti elötolás $0,1 \mathrm{~mm} /$ fog-ról $0,8 \mathrm{~mm} /$ fog-ra való növelése esetén a fajlagos forgácsolóerő mindegyik összetevője csökken, így az egységnyi forgácstérfogat leválasztásához szükséges energiafelhasználás is csökken. 


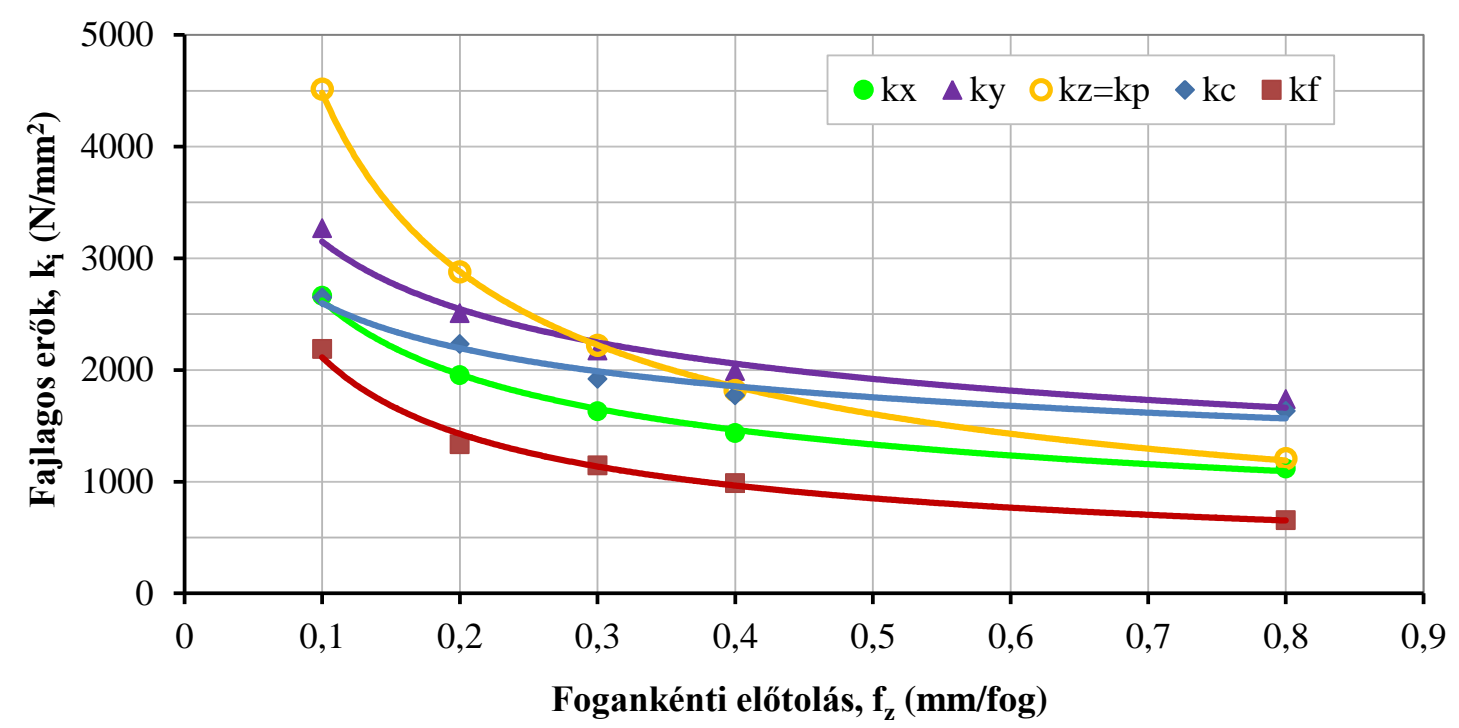

3. ábra. A fajlagos erőkomponensek maximális értékeinek változása a fogankénti elötolás függvényében

\section{A lapkageometria hatásának elemzése}

Az előzőekben bemutatott nyolcszögletü lapkával végzett kísérletek eredményeit kiegészítve egy korábbi cikkünk [13] eredményeivel összehasonlító elemzést végeztem, ahol az ipari gyakorlatban általánosan alkalmazott négy különféle geometriával (alakkal) rendelkező lapkával elvégzett kísérleteknél az energiafelhasználást vizsgáltam. A cél annak meghatározása volt, hogy melyik lapkageometriával végezhető el a legkisebb energia felhasználásával a homlokmarás során az egységnyi forgácstérfogat leválasztása, illetve milyen sorrendet lehet megadni a lapkageometriák szerint az energiaigényre vonatkozóan.

4. táblázat. A vizsgált lapkák jellemzőinek összefoglalása

\begin{tabular}{|c|c|c|c|}
\hline \multicolumn{2}{|c|}{ Lapkaalak } & \multirow{2}{*}{$\begin{array}{c}\text { Lapka típusa } \\
\text { Marófej típusa }\end{array}$} & \multirow{2}{*}{$\begin{array}{c}\text { Szerszám geometriai jellem- } \\
\text { zői }\end{array}$} \\
\hline Jel & Megnevezés & & \\
\hline & kör & $\begin{array}{c}\text { RCKT1204M0-PM } \\
\text { Sandvik R200-068Q27-12L }\end{array}$ & $\gamma_{0}=0^{\circ} ; \alpha_{0}=7^{\circ}$ \\
\hline & négyzet & $\begin{array}{l}\text { SEKN } 1203 \text { AFTN JC5030 } \\
\text { Canela 0748.90.063 }\end{array}$ & $\begin{array}{c}\kappa_{\mathrm{r}}=45^{\circ} ; \gamma_{\mathrm{o}}=0^{\circ} ; \alpha_{\mathrm{o}}=20^{\circ} \\
0,85 \times 45^{\circ}\end{array}$ \\
\hline & nyolcszög & $\begin{array}{c}\text { OCKX 0606-AD-TR HC4640 } \\
\text { ATORN } 10612120\end{array}$ & $\begin{array}{c}\kappa_{\mathrm{r}}=43^{\circ} ; \gamma_{\mathrm{o}}=25^{\circ} ; \alpha_{\mathrm{o}}=7^{\circ} \\
\mathrm{r}_{\varepsilon}=0,5 \mathrm{~mm}\end{array}$ \\
\hline 0 & téglalap & $\begin{array}{c}\text { R215.44-15T308M-WL } \\
\text { Sandvik R252.44-080027-15M }\end{array}$ & $\begin{array}{c}\kappa_{\mathrm{r}}=90^{\circ} ; \gamma_{\mathrm{o}}=0^{\circ} ; \alpha_{\mathrm{o}}=11^{\circ} \\
\mathrm{r}_{\varepsilon}=0,8 \mathrm{~mm}\end{array}$ \\
\hline
\end{tabular}



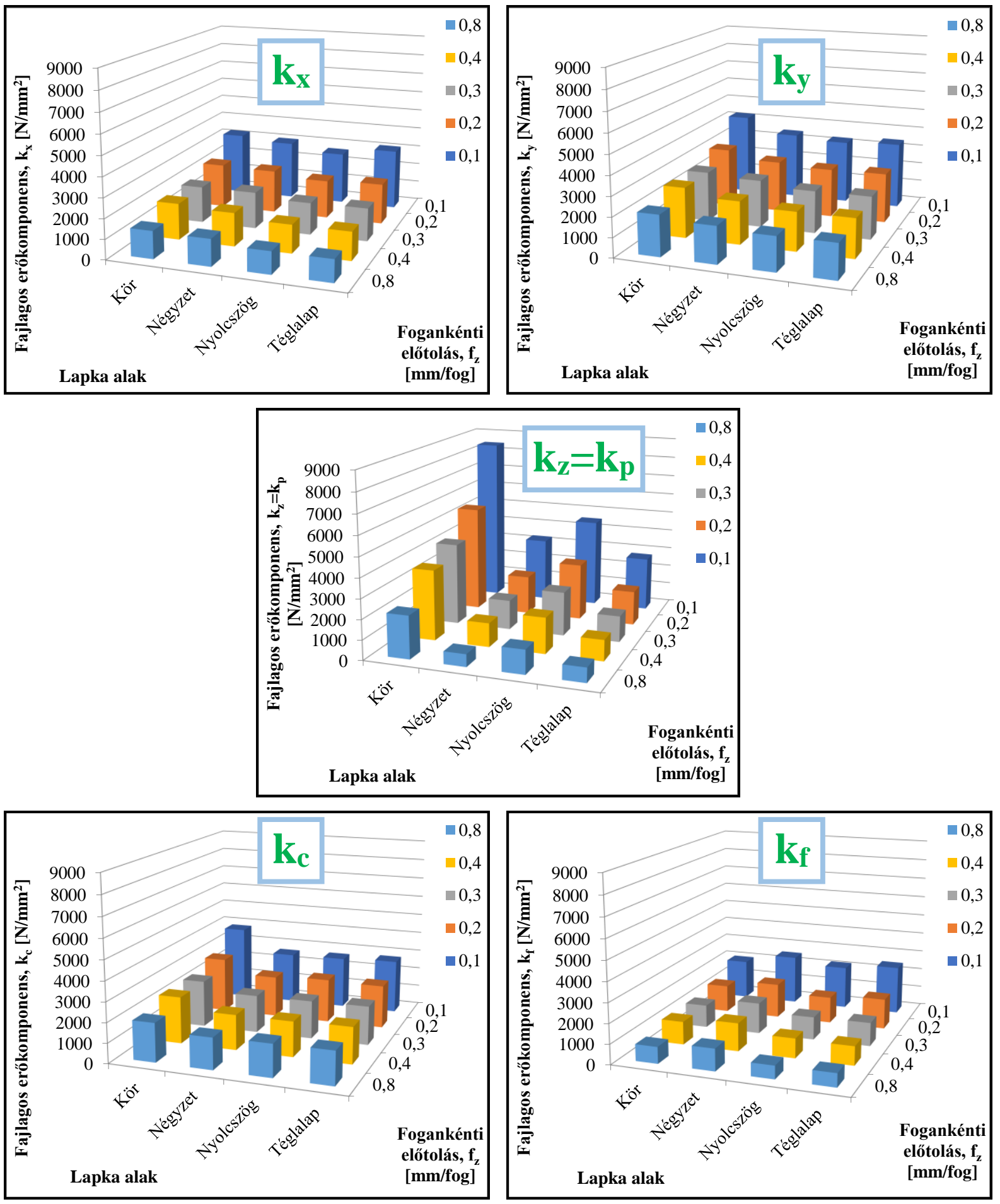

4. ábra. A fajlagos erőkomponensek maximális értékeinek változása a fogankénti elötolás függvényében a négyféle lapkatípus esetében 
A különböző alakkal rendelkező lapkák eltérő élgeometriával rendelkeznek, különböző a főélelhelyezési szögük $\left(\kappa_{\mathrm{r}}\right)$, a hátszögük $\left(\alpha_{0}\right)$ és a csúcssugaruk $\left(\mathrm{r}_{\varepsilon}\right)$, amelyek a szerszám forgácsolóélére és a munkadarabra ható eltérő terheléshez vezetnek. A kísérletek azonos feltételek mellett zajlottak az öszszehasonlíthatóság végett: a C45 alapanyagú acél munkadarabok homlokmarása $0,8 \mathrm{~mm}$ fogásmélységgel és $200 \mathrm{~m} / \mathrm{min}$ forgácsolósebességgel történt ugyanazon ötféle fogankénti előtolással $(0,1-0,8$ $\mathrm{mm} / \mathrm{fog}$ ). Az összes kísérlet száraz megmunkálási körülmények között, szimmetrikus munkadarabszerszám elrendezés mellett lett végrehajtva. A kísérletek során alkalmazott és vizsgált négyféle lapka típusa és föbb geometriai jellemzői a 4. táblázatban láthatók összefoglalva.

A 4. ábrán jól látható, hogy mindegyik lapkatípus estében a fogankénti előtolás növelésével mindegyik fajlagos erőkomponens értéke egyértelmủen csökkent. A részletes elemzést az alábbiakban fajlagos erökomponensenként közlöm:

- A $\mathrm{k}_{\mathrm{x}}$ komponens esetében a legkisebb értékek a nyolcszög alakú lapkánál adódtak, a két legnagyobb fogankénti előtolás esetében pedig a téglalap alakú lapkánál és a nyolcszög alakú lapkánál azonos értékeket tapasztaltam. Egyéb esetekben a $\mathrm{k}_{\mathrm{x}}$ komponensek aránya a téglalap alakú lapkánál a nyolcszög alakú lapkához viszonyítva 102-106\%. Viszonyítási alapként felhasználva a nyolcszög alakú lapkánál található értékeket az arány a négyzet alakú lapkánál 113-120\%, míg a kör alakú lapkánál 113-127\%.

- A $\mathrm{k}_{\mathrm{y}}$ komponens esetében a $\mathrm{k}_{\mathrm{x}}$ komponensnél leírtakhoz hasonló jelleget tapasztaltam, itt is a legkisebb értékek a nyolcszög alakú lapkánál adódtak. Viszonyítási alapként felhasználva a nyolcszög alakú lapkánál található értékeket az arány a téglalap alakú lapkánál 101-104\%, a négyzet alakú lapkánál 105-111\%, a kör alakú lapkánál pedig 118-129\%.

- $\mathrm{A} \mathrm{k}_{\mathrm{z}}\left(=\mathrm{k}_{\mathrm{p}}\right)$ komponens esetében a legkisebb értékek a téglalap alakú lapkánál adódtak, kivétel a legnagyobb fogankénti előtolásnál volt, ahol a négyzet alakú lapka alkalmazásával 15\%-kal kisebb érték jelent meg. Viszonyítási alapként felhasználva a téglalap alakú lapkánál található értékeket az arány a négyzet alakú lapkánál 113-119\% (a kivételtől eltekintve), a nyolcszög alakú lapkánál 164-172\%, a kör alakú lapkánál pedig 294-338\%. Ennél a komponensnél figyelhető meg a legnagyobb szóródás az értékeknél.

- A $\mathrm{k}_{\mathrm{c}}$ komponens esetében a legkisebb értékek a négyzet alakú lapkánál adódtak, a $0,4 \mathrm{~mm} / \mathrm{fog}$ fogankénti előtolás esetében pedig a négyzet alakú lapkánál és a nyolcszög alakú lapkánál azonos értékeket tapasztaltam. Egyéb esetekben a $\mathrm{k}_{\mathrm{c}}$ komponensek aránya a nyolcszög alakú lapkánál a négyzet alakú lapkához viszonyítva 101-106\%. Viszonyítási alapként felhasználva a négyzet alakú lapkánál található értékeket az arány a téglalap alakú lapkánál közel azonos (103106\%), míg a kör alakú lapkánál 123-146\%.

- $\mathrm{A} \mathrm{k}_{\mathrm{f}}$ komponens esetében nem lehet egyértelmüen megadni a legkisebb értékekkel rendelkező lapkaalakot. Viszonyítási alapnak a nyolcszög alakú lapkánál található értékeket választottam, így az arány a téglalap alakú lapkánál $97-115 \%$, a kör alakú lapkánál 92-127\%, a négyzet alakú lapkánál pedig 114-168\%.

Mind a munkadarabra ható erő komponenseiből meghatározott fajlagos erőkomponens értékek $\left(\mathrm{k}_{\mathrm{x}}, \mathrm{k}_{\mathrm{y}}\right.$, $\mathrm{k}_{\mathrm{z}}$ ), mind a szerszám (lapka) élére ható erő komponenseiből meghatározott fajlagos erőkomponens értékek $\left(\mathrm{k}_{\mathrm{c}}, \mathrm{k}_{\mathrm{f}}, \mathrm{k}_{\mathrm{p}}\right)$ alapján az energiafelhasználás szempontjából a vizsgált négyféle lapkageometria (alak) felhasználását az alábbi sorrendben javaslom: négyzet, téglalap, nyolcszög, kör.

\section{5. Összefoglalás}

A cikk első részében egy homlokmarási kísérlet eredményeit mutatom be. A szimmetrikus homlokmarás nyolcszög alakú (oktagonális) lapkával volt elvégezve, állandó fogásmélység és állandó forgácso- 
lósebesség mellett ötféle fogankénti előtolás esetén forgácsolási erőmérést végeztem. Megvizsgáltam az anyagleválasztás energiaigényét a fajlagos forgácsolóerő változásán keresztül. A fogankénti előtolás növelésével mindegyik erőkomponens értéke növekedett. A kísérletek eredményei alapján azt a megállapítást tettem, hogy az alkalmazott paraméterek esetén a fogankénti előtolás $0,1 \mathrm{~mm} / \mathrm{fog}$-ról 0,8 $\mathrm{mm} /$ fog-ra való növelésével a fajlagos forgácsolóerő mindegyik összetevője csökkent, tehát az egységnyi forgácstérfogat leválasztásához szükséges energiafelhasználás is csökkent.

Ezt követően a négyféle alakú lapkával elvégzett kísérleteknél az energiaigényt vizsgáltam. Az azonos feltételek mellett elvégzett kísérletek lehetővé tették a lapkageometria hatásának összehasonlító elemzését. A különböző alakú lapkáknál az élgeometria eltérése miatt a fellépő erőknél (erö összetevőknél) is különbség mutatkozott. A fajlagos erö összetevőinek vizsgálatával megállapítottam, hogy szimmetrikus homlokmarásnál az alkalmazott paramétertartományban az egységnyi forgácstérfogat leválasztásához a legkisebb energia a négyzet alakú lapkánál szükséges. A további javasolt sorrend: téglalap, nyolcszög, majd kör alakú lapka.

\section{Köszönetnyilvánítás}

A cikkben ismertetett kutatómunka az EFOP-3.6.1-16-2016-00011 jelü Fiatalodó és Megújuló Egyetem - Innovativ Tudásváros - a Miskolci Egyetem intelligens szakosodást szolgáló intézményi fejlesztése projekt részeként - a Széchenyi 2020 keretében - az Európai Unió támogatásával, az Európai Szociális Alap társfinanszírozásával valósul meg.

\section{Irodalom}

[1] Karpuschewski, B., Kundrák, J., Emmer, T., Borysenko, D. (2017). A new strategy in face milling - inverse cutting technology. Solid State Phenomena, Volume 261, pp. 331-338. https://doi.org/10.4028/www.scientific.net/SSP.261.331

[2] Li, X. P., Zheng, H. Q., Wong, Y. S., Nee, A. Y. C. (2000). An approach to theoretical modeling and simulation of face milling forces. Journal of Manufacturing Processes, Volume 2, Issue 4, pp. 225-240. https://doi.org/10.1016/S1526-6125(00)70024-7

[3] Felhő, C., Kundrák, J. (2014). Comparison of theoretical and real surface roughness in face milling with octagonal and circular inserts. Key Engineering Materials, Volume 581, pp. 360365. https://doi.org/10.4028/www.scientific.net/KEM.581.360

[4] Kundrák, J., Felhö, C. (2016). 3D roughness parameters of surfaces face milled by special tools. Manufacturing Technology, Volume 16, Issue 3, pp. 532-538. https://doi.org/10.21062/ujep/x.2016/a/1213-2489/MT/16/3/532

[5] Zarkti, H., El Mesbahi, A., Rechia, A., Jaider, O. (2015). Towards an automatic-optimized tool selection for milling process, based on data from Sandvik Coromant, Xème Conférence Internationale: Conception et Production Intégrées, Tanger, Morocco.

[6] Antonialli, A. I. S., Diniz, A. E., Pederiva, R. (2010). Vibration analysis of cutting force in titanium alloy milling. International Journal of Machine Tools and Manufacture, Volume 50, Issue 1, pp. 65-74. https://doi.org/10.1016/j.ijmachtools.2009.09.006

[7] Ghorbani, H., Moetakef-Imani, B.: Specific cutting force and cutting condition interaction modeling for round insert face milling operation. International Journal of Advanced Manufacturing Technology, Volume 84, Issues 5-8, pp. 1705-1715.

https://doi.org/10.1007/s00170-015-7985-2 
[8] Korkut, I., Donertas, M. A. (2007). The influence of feed rate and cutting speed on the cutting forces, surface roughness and tool-chip contact length during face milling. Materials \& Design, Volume 28, Issue 1, pp. 308-312. https://doi.org/10.1016/j.matdes.2005.06.002

[9] Gurdal, O., Wright, A., Carpenter, C., Blackmore, M.: Investigation of the performance of different face milling inserts to improve rough milling of SA508 Grade 3 forgings. In: Proceedings of the ASME 2018 Pressure Vessels and Piping Conference PVP 2018, Prague, Czech Republic, https://doi.org/10.1115/PVP2018-84337

[10] Suresh Kumar Reddy, N., Venkateswara Rao, P. (2005). Selection of optimum tool geometry and cutting conditions using a surface roughness prediction model for end milling. International Journal of Advanced Manufacturing Technology, Volume 26, pp. 1202-1210. https://doi.org/10.1007/s00170-004-2110-y

[11] Kundrák, J., Markopoulos, A. P., Makkai, T., Deszpoth, I., Nagy, A. (2018). Analysis of the effect of feed on chip size ratio and cutting forces in face milling for various cutting speeds. Manufacturing Technology, Volume 18, Issue 3, pp. 431-438. https://doi.org/10.21062/ujep/117.2018/a/1213-2489/MT/18/3/431

[12] Kundrák, J., Gyáni, K., Felhő, C., Deszpoth, I. (2017). The effect of the shape of chip cross section on cutting force and roughness when increasing feed in face milling. Manufacturing Technology, Volume 17, Issue 3, pp. 335-342.

https://doi.org/10.21062/ujep/x.2017/a/1213-2489/MT/17/3/335

[13] Kundrák, J., Markopoulos, A. P., Makkai, T., Karkalos, N. E. (2019). Effect of edge geometry on cutting forces in face milling with different feed rates. Manufacturing Technology, Volume 19, Issue 6, pp. 984-992. https://doi.org/10.21062/ujep/407.2019/a/1213-2489/MT/19/6/984

[14] Makkai, T. (2020). A forgácsolóerő vizsgálata nyolcszögletü lapkával végzett homlokmarásnál. Multidiszciplináris Tudományok, Volume 7, Issue 3, pp. 285-293.

https://doi.org/10.35925/j.multi. 2020.3.34 